\title{
Nawyki żywieniowe u pacjentów z cukrzycą typu 2
}

\author{
Eating habits in patients with type 2 diabetes
}

\author{
ANNA ANTCZAK-KOMOTERSKA ${ }^{1}$ \\ MALWINA GOŁĘBIEWSKA² \\ ${ }^{1}$ Instytut Nauk o Zdrowiu, PUZ we Włocławku \\ 2 MZOZ Przychodnia numer 6 Poradnia Dziecięca ul. Kaliska 104a we Włocławku
}

DOI: http://dx.doi.org/10.21784/IwP.2020.013

ISSN: 2451-1846

\section{Streszczenie:}

Wstęp. Cukrzyca jest przewlekłym schorzeniem, którego przyczyną jest zaburzenie wydzielana insuliny. Dieta jest bardzo istotnym elementem terapii cukrzycy. Warunkuje ona utrzymanie właściwego stężenia glukozy i tłuszczów (lipidów) we krwi oraz optymalne wartości ciśnienia tętniczego. Dobrze dobrana dieta zmniejsza ryzyko wystąpienia powikłań cukrzycy, jak również redukuje ryzyko chorób naczyniowych. Właściwy model żywienia odgrywa także ważną rolę w prewencji i leczeniu przewlekłych powikłań cukrzycy (mikroangiopatii, retinopatii i nefropatii cukrzycowej.

Cel. Celem niniejszej pracy byłą ocena wpływu nawyków żywieniowych na pacjentów z cukrzycą typu 2.

Materiał i metody. W pracy wykorzystano metodę sondażu diagnostycznego. Technikami badawczymi, jakimi posłużono się dla potrzeb procesu badawczego były: ankietowanie oraz technika skali szacunkowej. Narzędziem, które zostało użyte w badaniu był autorskim kwestionariusz ankiety własnej. 
Wyniki. Wyniki badań przedstawiają, że pacjentki posiadają dobre i złe nawyki żywieniowe. Pozytywne zachowania dotyczą liczby posiłków i sposobu przyrządzania potraw. Najwięcej kobiet wskazało, że w ciągu dnia spożywa 45 posiłków - 39,0\%. Do negatywnych zaliczymy podjadanie między posiłkami (najwięcej kobiet wskazało, że czasami dojada między posiłkami - 58,0\%, najmniej że nie - 8,0\%), wysoką konsumpcję słodyczy (najwięcej kobiet wskazało, że słodycze spożywa kilka razy dziennie - 23,0\%, najmniej wskazało, że 3-4 razy na tydzień - 13,0\%), oraz mniejszą częstotliwość wybierania ryb w porównaniu z kobietami zdrowymi.

Wnioski. Okazuje się, że poziom wiedzy na temat pozytywnych nawyków żywieniowych jest na średnim poziomie. Celem działań prewencyjnych zatem jest uświadomienie społeczeństwu, jak ważna jest prawidłowa dieta, ilość przyjmowanych posiłków i sposób ich przyrządzania.

Słowa kluczowe: cukrzyca typu 2, dieta, nawyki żywieniowe.

\section{Summary:}

Admission. Diabetes mellitus is a chronic disease caused by a disturbance in insulin secretion. Diet is a very important element in the treatment of diabetes. It is a prerequisite for maintaining the proper concentration of glucose and fats (lipids) in the blood and optimal blood pressure. A well-chosen diet reduces the risk of diabetes complications and reduces the risk of vascular diseases. An appropriate nutrition model also plays an important role in the prevention and treatment of chronic diabetes complications (microangiopathy, retinopathy and diabetic nephropathy).

Aim. The aim of this study was to evaluate the influence of eating habits on patients with type 2 diabetes.

Material and methods. The paper uses the method of a diagnostic survey. The research techniques that were used for the purposes of the research process were: surveying and estimation scale technique. The tool that was used in the study was the proprietary questionnaire of the self-survey.

Results. The research results show that the patients have good and bad eating habits. Positive behaviors relate to the number of meals and the way of cooking. Most women indicated that they eat 4-5 meals a day -39,0\%. The negative 
ones include snacking between meals (most women indicated that they sometimes eat between meals $-58,0 \%$, the least that not - 8,0\%), high consumption of sweets (most women indicated that they eat sweets several times a day $23,0 \%$, the least indicated that 3-4 times a week - 13,0\%), and lower frequency of selecting fish compared to healthy women.

Conclusions. It turns out that the level of knowledge about positive eating habits is average. Therefore, the aim of preventive actions is to make the public aware of the importance of a proper diet, the number of meals taken and the way of their preparation.

Keywords: type 2 diabetes, diet, eating habits.

\section{Wstęp}

Cukrzyca przypisana jest do grupy chorób metabolicznych o różnej etiologii, patogenezie, obrazie klinicznym i sposobie leczenia. Charakteryzuje się głównie przewlekłą hiperglikemią, która wynika z defektu wydzielania insuliny. Długotrwała hiperglikemia prowadzić może do uszkodzenia, zaburzenia czynności i niewydolności różnych narządów w szczególności oczu nerek, serca i naczyń krwionośnych [1].

Cukrzyca jest najszybciej rozprzestrzeniającą się chorobą w obecnych czasach, dlatego przez niektóre źródła jest nazywana epidemią XXI wieku [2]. W Polsce zachorowalność na cukrzycę wynosi do 3,7\% wśród całej populacji. Przedstawiono również, że ryzyko zachorowania na cukrzycę typu 2 przejawiają 4 mln osób ze społeczeństwa [3].

Tak wysoka liczba osób chorych powoduje wzrost ilości powikłań wynikających z postępu choroby w wielu narządach, co skutkuje znacznym wpływem na długość i jakość życia. Lekarze szacują, że umieralność na cukrzycę ukaże się w 70\% podczas przebiegu powikłań wynikających ze strony układu sercowo- naczyniowego [4].

Leczenie cukrzycy jest procesem ciągłym, uwarunkowanym postępem wiedzy i zwiększeniem możliwości terapeutycznych, dążącym do osiągnięcia celu głównego - poprawy jakości życia chorego [5]. Jest to 
ogromne wyzwanie dla współczesnej diabetologii i całego systemu opieki zdrowotnej, ponieważ pomimo stosowania różnorodnych metod terapii tylko niektórzy osiągną optymalne wyrównanie metaboliczne [6].

Bardzo duże znaczenie w ustaleniu zasad leczenia cukrzycy typu 2 jak i metod oraz celów terapeutycznych ma podkreślenie znaczenia wartości indywidualizacji zasad zapobiegania, rozpoznawania oraz leczenia cukrzycy. Jednym z najistotniejszych elementów terapii jest leczenie dietetyczne [7].

\section{Cel}

Celem pracy była ocena wpływu nawyków żywieniowych na pacjentów z cukrzycą typu 2.

\section{Materiał i metody}

W pracy wykorzystano metodę sondażu diagnostycznego. techniki: ankietowanie oraz technika skali szacunkowej. Narzędziem, które zostało użyte $\mathrm{w}$ badaniu był autorskim kwestionariusz ankiety własnej.

Badanie zostało przeprowadzone z zachowaniem całkowitej anonimowości w Poradni Cukrzycowej we Włocławku przy ul. Wyszyńskiego 27. Sondaż diagnostyczny objął 100 respondentów, w tym 50 kobiet w wieku od 45 do 65 lat, zmagających się z cukrzycą typu 2, a także 50 kobiet nie chorujących na cukrzyce typu 2. Najliczniejszą grupę stanowili badani w wieku 45-50 lat - 38,0\%, najmniej liczną w wieku 61-65 lat - 26,0\%. Najwięcej kobiet mieszkało w mieście $53,0 \%$. Najliczniejszą grupę stanowiły pracujące umysłowo - 37,0\%, najmniej liczną renciści z powodu cukrzycy - 2,0\%.

Otrzymane kwestionariusze każda osoba badana wypełniała dobrowolnie, samodzielnie oraz bez narzuconych ograniczeń czasowych. 
Uzyskane wyniki badań poddano analizie statystycznej testem $\chi 2$ dla prób niezależnych. Przyjęto 5\% ryzyko błędu wnioskowania.

\section{Wyniki}

W tabeli 1 zaprezentowano występowanie wśród respondentów nadwagi bądź otyłości.

Tab.1. Występowanie nadwagi bądź otyłości.

\begin{tabular}{|c|c|c|c|c|c|}
\hline \multicolumn{1}{|c|}{ Grupa } & \multicolumn{2}{|c|}{ kontrolna } & \multicolumn{2}{c|}{ badana } & razem \\
\hline Odpowiedź & liczba & $\%$ & liczba & $\%$ & liczba \\
\hline TAK & 15 & 30,0 & 15 & 30,0 & 30 \\
\hline NIE & 35 & 70,0 & 35 & 70,0 & 70 \\
\hline Razem & 50 & 100,0 & 50 & 100,0 & 100 \\
\hline
\end{tabular}

Jak wynika z tabeli 1 większość badanych wskazała, że nie ma nadwagi bądź otyłości - 70,0\%. W grupie kontrolnej - 35 osób (70,0\%), w grupie badanej - 35 osób (70,0\%).

W tabeli 2 przedstawiono średnie wskaźnika BMI w badanych grupach.

Tab.2. Średnie wskaźnika BMI w badanych grupach.

\begin{tabular}{|l|c|c|c|c|c|c|c|c|c|c|}
\hline Grupa & $\mathrm{N}$ & Średnia & $\mathrm{SD}$ & $\begin{array}{r}\text { Ufność } \\
-95,0 \%\end{array}$ & $\begin{array}{c}\text { Ufność } \\
+95,0 \%\end{array}$ & Min. & Maks. & Q25 & Mediana & Q75 \\
\hline Kontrolna & 50 & 27,38 & 6,537 & 25,52 & 29,24 & 19,33 & 43,25 & 22,76 & 25,16 & 31,51 \\
\hline Badana & 50 & 28,16 & 5,751 & 26,52 & 29,79 & 19,84 & 45,79 & 24,22 & 27,14 & 31,22 \\
\hline Razem & 100 & 27,77 & 6,138 & 26,55 & 28,99 & 19,33 & 45,79 & 23,24 & 26,44 & 31,23 \\
\hline
\end{tabular}


Jak wynika z tabeli 2 średnia wskaźnika BMI wyniosła - 27,77 punktu. Odchylenie standardowe stanowiło 22,1\% wartości średniej, co świadczy o przeciętnym zróżnicowaniu wyników. Średnio wyższy wynik odnotowano w grupie badanej - 28,16 punktu, w grupie kontrolnej - 27,38 punktu. Wynik minimalny zbliżony, niższy w grupie kontrolnej - 19,33 punktu, maksymalny zróżnicowany, wyższy w grupie badanej $-45,79$ punktu.

W tabeli 3 zaprezentowano wskaźnik BMI.

Tab. 3. Wskaźnik BMI.

\begin{tabular}{|l|c|c|c|c|c|}
\hline \multicolumn{1}{|c|}{ Grupa } & \multicolumn{2}{c|}{ kontrolna } & \multicolumn{2}{c|}{ badana } & razem \\
\hline \multicolumn{1}{|c|}{ BMI } & liczba & $\%$ & liczba & $\%$ & liczba \\
\hline wartość prawidłowa & 25 & 50,0 & 19 & 38,0 & 44 \\
\hline nadwaga & 11 & 22,0 & 16 & 32,0 & 27 \\
\hline I stopień otyłości & 6 & 12,0 & 10 & 20,0 & 16 \\
\hline II stopień otyłości & 4 & 8,0 & 2 & 4,0 & 6 \\
\hline III stopień otyłości & 4 & 8,0 & 3 & 6,0 & 7 \\
\hline Razem & 50 & 100,0 & 50 & 100,0 & 100 \\
\hline
\end{tabular}

Jak wynika z tabeli 3 najwięcej kobiet to osoby z wartością prawidłową BMI - 44,0\%. W grupie kontrolnej - 25 osób (50,0\%), w grupie badanej - 19 osób (38,0\%). Najmniej kobiet to osoby z II stopniem otyłości $-6,0 \%$. Podobnie w grupie badanej - 2 osoby (4,0\%), w grupie kontrolnej z II i III stopniem otyłości - po 4 osoby (po 8,0\%).

W tabeli 4 przedstawiono dzienna ilość spożywanych posiłków przez badanych. 
Tab.4. Dzienna ilość spożywanych posiłków.

\begin{tabular}{|l|c|c|c|c|c|}
\hline \multicolumn{1}{|c|}{ Grupa } & \multicolumn{2}{c|}{ kontrolna } & \multicolumn{2}{c|}{ badana } & razem \\
\hline Liczba posiłków & liczba & $\%$ & liczba & $\%$ & liczba \\
\hline 1-2 posiłków & 9 & 18,0 & 2 & 4,0 & 11 \\
\hline 3-4 posiłków & 24 & 48,0 & 11 & 22,0 & 35 \\
\hline 4-5 posiłków & 15 & 30,0 & 24 & 48,0 & 39 \\
\hline sześć & 2 & 4,0 & 11 & 22,0 & 13 \\
\hline > sześciu & 0 & 0,0 & 2 & 4,0 & 2 \\
\hline Razem & 50 & 100,0 & 50 & 100,0 & 100 \\
\hline
\end{tabular}

Jak wynika z tabeli 4 najwięcej kobiet wskazało, że w ciągu dnia spożywa 4-5 posiłków - 39,0\%, najmniej wskazało, że >sześciu posiłków - 2,0\%. W grupie kontrolnej odpowiednio 34 posiłków - 24 osoby $(48,0 \%)$ i sześć posiłków - 2 osoby $(4,0 \%)$, w grupie badanej 4-5 posiłków - 24 osoby $(48,0 \%)$ oraz 1-2 posiłków bądź >sześciu posiłków - po 2 osoby ( $4,0 \%)$.

W tabeli 5 zaprezentowano czas przerwy między posiłkami.

Tab.5. Czas przerwy między posiłkami.

\begin{tabular}{|l|c|c|c|c|c|}
\hline \multicolumn{1}{|c|}{ Grupa } & \multicolumn{2}{c|}{ kontrolna } & \multicolumn{2}{c|}{ badana } & razem \\
\hline Czas & liczba & $\%$ & liczba & $\%$ & liczba \\
\hline około 1 godziny & 0 & 0,0 & 1 & 2,0 & 1 \\
\hline około 2-3 godzin & 16 & 32,0 & 23 & 46,0 & 39 \\
\hline około 4-5 godzin & 21 & 42,0 & 7 & 14,0 & 28 \\
\hline$>5$ godzin & 1 & 2,0 & 3 & 6,0 & 4 \\
\hline nie jem regularnie & 12 & 24,0 & 16 & 32,0 & 28 \\
\hline Razem & 50 & 100,0 & 50 & 100,0 & 100 \\
\hline
\end{tabular}


Jak wynika z tabeli 5 najwięcej kobiet wskazało, że przerwa miedzy posiłkami trwa zwykle około 23 godzin - 39,0\%, najmniej wskazało, że około 1 godziny - 1,0\%. W grupie kontrolnej odpowiednio około $4-5$ godzin -21 osób $(42,0 \%)$ oraz $>5$ godzin -1 osoba $(2,0 \%)$, w grupie badanej około $2-3$ godzin -23 osoby $(46,0 \%)$ oraz około 1 godziny - 1 osoba $(2,0 \%)$.

W tabeli 6 przedstawiono deklaracje dotyczące dojadania między posiłkami.

Tab.6. Dojadanie między posiłkami.

\begin{tabular}{|l|c|c|c|c|c|}
\hline \multicolumn{1}{|c|}{ Grupa } & \multicolumn{2}{c|}{ kontrolna } & \multicolumn{2}{c|}{ badana } & razem \\
\hline Odpowiedź & liczba & $\%$ & liczba & $\%$ & liczba \\
\hline Tak, często & 18 & 36,0 & 17 & 34,0 & 34 \\
\hline Tak, tylko czasami & 29 & 58,0 & 28 & 56,0 & 58 \\
\hline Nie & 3 & 6,0 & 5 & 10,0 & 8 \\
\hline Razem & 50 & 100,0 & 50 & 100,0 & 100 \\
\hline
\end{tabular}

Najwięcej kobiet wskazało, że czasami dojada między posiłkami $58,0 \%$, najmniej że nie - 8,0\%. W grupie kontrolnej odpowiednio czasami - 29 osób $(59,0 \%)$ oraz nie -3 osoby $(6,0 \%)$, w grupie badanej czasami - 28 osób (56,0\%) oraz nie - 5 osób $(10,0 \%)$.

W tabeli 7 zaprezentowano opinie respondentów dotyczące dziennej ilości wypijanych płynów. 
Tab.7. Dzienna ilość wypijanych płynów.

\begin{tabular}{|l|c|c|c|c|c|}
\hline \multicolumn{1}{|c|}{ Grupa } & \multicolumn{2}{c|}{ kontrolna } & \multicolumn{2}{c|}{ badana } & razem \\
\hline Ilość płynów & liczba & $\%$ & liczba & $\%$ & liczba \\
\hline$<0,5$ litra & 1 & 2,0 & 1 & 2,0 & 2 \\
\hline $0,5-1$ litra & 15 & 30,0 & 21 & 42,0 & 36 \\
\hline $1-1,5$ litra & 24 & 48,0 & 16 & 32,0 & 40 \\
\hline$>1,5$ litra & 10 & 20,0 & 12 & 24,0 & 22 \\
\hline Razem & 50 & 100,0 & 50 & 100,0 & 100 \\
\hline
\end{tabular}

Jak wynika z tabeli 7 najwięcej kobiet wskazało, że w ciągu dnia wypija 1-1,5 litra - 40,0\%, najmniej wskazało, że <0,5 litra - 2,0\%. W grupie kontrolnej odpowiednio 1-1,5 litra - 24 osoby (48,0\%) oraz $<0,5$ litra - 1 osoba (2,0\%), w grupie badanej 0,5-1 litra - 21 osób $(42,0 \%)$ oraz $<0,5$ litra -1 osoba $(2,0 \%)$.

W tabeli 8 przedstawiono opinie respondentów dotyczące znajomości wartości odżywczych produktów.

Tab.8. Znajomość wartości odżywczych produktów.

\begin{tabular}{|l|c|c|c|c|c|}
\hline \multicolumn{1}{|c|}{ Grupa } & \multicolumn{2}{|c|}{ kontrolna } & \multicolumn{2}{c|}{ badana } & razem \\
\hline Odpowiedź & liczba & $\%$ & liczba & $\%$ & liczba \\
\hline $\begin{array}{l}\text { Tak, zawsze sprawdzam ilość } \\
\text { poszczególnych składników } \\
\text { pokarmowych }\end{array}$ & 7 & 14,0 & 4 & 8,0 & 11 \\
\hline $\begin{array}{l}\text { Tak, zawsze sprawdzam ale } \\
\text { tylko ilość węglowodanów }\end{array}$ & 3 & 6,0 & 7 & 14,0 & 10 \\
\hline $\begin{array}{l}\text { Tylko czasami znam wartość od- } \\
\text { żywczą spożywanych posiłków }\end{array}$ & 18 & 36,0 & 16 & 32,0 & 34 \\
\hline $\begin{array}{l}\text { Nie, nigdy nie zastanawiał się } \\
\text { nad tym }\end{array}$ & 22 & 44,0 & 23 & 46,0 & 45 \\
\hline Razem & 50 & 100,0 & 50 & 100,0 & 100 \\
\hline
\end{tabular}


Jak wynika z tabeli 8 najwięcej kobiet wskazało, że wartości odżywczych produktów nigdy się nad tym nie zastanawiało - 45,0\%, najmniej wskazało, że tak, zawsze sprawdzam ale tylko ilość węglowodanów - 10,0\%. W grupie kontrolnej odpowiednio nigdy się nad tym nie zastanawiało - 22 osoby (44,0\%) oraz tak, zawsze sprawdzam ale tylko ilość węglowodanów - 3 osoby (6,0\%), w grupie badanej nigdy się nad tym nie zastanawiało - 23 osoby $(46,0 \%)$ oraz tak, zawsze sprawdzam ilość poszczególnych składników pokarmowych - 4 osoby $(8,0 \%)$.

W tabeli 9 zaprezentowano opinie respondentów dotyczące dziennej częstości spożywanego mleka i produktów mlecznych.

Tab. 9. Dzienna częstość spożywanego mleka i produktów mlecznych.

\begin{tabular}{|l|c|c|c|c|c|}
\hline \multicolumn{1}{|c|}{ Grupa } & \multicolumn{2}{c|}{ kontrolna } & \multicolumn{2}{c|}{ badana } & razem \\
\hline Odpowiedź & liczba & $\%$ & liczba & $\%$ & liczba \\
\hline Nie spożywam & 9 & 18,0 & 12 & 24,0 & 21 \\
\hline 1-2 razy & 30 & 60,0 & 26 & 52,0 & 56 \\
\hline 3-4 razy & 11 & 22,0 & 10 & 20,0 & 21 \\
\hline 5 i więcej razy & 0 & 0,0 & 2 & 4,0 & 2 \\
\hline Razem & 50 & 100,0 & 50 & 100,0 & 100 \\
\hline
\end{tabular}

Jak wynika z tabeli 9 najwięcej kobiet wskazało, że mleko i przetwory mleczne spożywa dziennie 12 razy $-56,0 \%$, najmniej wskazało, że 5 i więcej razy - 2,0\%. W grupie kontrolnej odpowiednio 1-2 razy 30 osób (60,0\%) oraz nie spożywam - 9 osób $(18,0 \%)$, w grupie badanej 1-2 razy - 26 osób (52,0\%) oraz 5 i więcej razy - 2 osoby $(4,0 \%)$.

W tabeli 10 przedstawiono opinie respondentów dotyczące częstości spożywania słodyczy. 
Tab.10. Częstość spożywania słodyczy.

\begin{tabular}{|l|c|c|c|c|c|}
\hline \multicolumn{1}{|c|}{ Grupa } & \multicolumn{2}{c|}{ kontrolna } & \multicolumn{2}{c|}{ badana } & razem \\
\hline Częstość & liczba & $\%$ & liczba & $\%$ & liczba \\
\hline Kilka razy dziennie & 18 & 36,0 & 5 & 10,0 & 23 \\
\hline Raz dziennie & 8 & 16,0 & 14 & 28,0 & 22 \\
\hline 3-4 razy na tydzień & 11 & 22,0 & 2 & 4,0 & 13 \\
\hline 1-2 razy na tydzień & 8 & 16,0 & 12 & 24,0 & 20 \\
\hline Nie spożywam & 5 & 10,0 & 17 & 34,0 & 22 \\
\hline Razem & 50 & 100,0 & 50 & 100,0 & 100 \\
\hline
\end{tabular}

Jak wynika z tabeli 10 Najwięcej kobiet wskazało, że słodycze spożywa kilka razy dziennie - 23,0\%, najmniej wskazało, że 3-4 razy na tydzień - 13,0\%. W grupie kontrolnej odpowiednio kilka razy dziennie - 18 osób (36,0\%) oraz nie spożywam - 5 osób (10,0\%), w grupie badanej nie spożywam - 17 osób $(34,0 \%)$ oraz 3-4 razy na tydzień - 2 osoby $(4,0 \%)$.

W tabeli 11 zaprezentowano opinie ankietowanych dotyczące rozumienia pojęcia BMI.

Tab. 11. Rozumienie pojęcia BMI.

\begin{tabular}{|c|c|c|c|c|c|}
\hline \multicolumn{1}{|c|}{ Grupa } & \multicolumn{2}{c|}{ kontrolna } & \multicolumn{2}{c|}{ badana } & razem \\
\hline Odpowiedź & liczba & $\%$ & liczba & $\%$ & liczba \\
\hline TAK & 36 & 72,0 & 29 & 58,0 & 65 \\
\hline NIE & 14 & 28,0 & 21 & 42,0 & 35 \\
\hline Razem & 50 & 100,0 & 50 & 100,0 & 100 \\
\hline
\end{tabular}


Jak wynika z tabeli 11 większość wskazała, że wie co oznacza pojęcie BMI - 65,0\%, w grupie kontrolnej- 36 osób (72,0\%), w grupie badanej - 29 osób (58,0\%).

W tabeli 12 przedstawiono opinie ankietowanych dotyczące różnic w wynikach nawyków żywieniowych pomiędzy badanymi grupami.

Tab.12. Opinie badanych dotyczące różnic w wynikach nawyków żywieniowych pomiędzy badanymi grupami.

\begin{tabular}{|c|c|c|c|c|c|c|c|c|c|c|}
\hline Pozycja & $\begin{array}{l}\text { Sum. } \\
\text { rang } \\
\text { kon- } \\
\text { trolna }\end{array}$ & $\begin{array}{l}\text { Sum. } \\
\text { rang } \\
\text { ba- } \\
\text { dana }\end{array}$ & U & $\mathrm{Z}$ & $\begin{array}{l}\text { Po- } \\
\text { ziom } \\
\text { p }\end{array}$ & $\begin{array}{l}\text { Z po- } \\
\text { praw. }\end{array}$ & $\begin{array}{l}\text { Po- } \\
\text { ziom } \\
\mathrm{p}\end{array}$ & $\begin{array}{c}\mathrm{N} \\
\text { ważn. } \\
\text { kon- } \\
\text { trolna }\end{array}$ & $\begin{array}{c}\mathrm{N} \\
\text { ważn. } \\
\text { ba- } \\
\text { dana }\end{array}$ & $\begin{array}{l}2 * 1 \text { str. } \\
\text { dokł. p }\end{array}$ \\
\hline $\begin{array}{l}\text { ile posiłków } \\
\text { spożywa w } \\
\text { ciągu dnia }\end{array}$ & 1924,0 & 3126,0 & 649,0 & $\begin{array}{c}- \\
4,140\end{array}$ & 0,000 & $\begin{array}{c}- \\
4,377\end{array}$ & 0,000 & 50 & 50 & 0,000 \\
\hline $\begin{array}{l}\text { przerwa mię- } \\
\text { dzy kolejnymi } \\
\text { posiłkami }\end{array}$ & 2589,0 & 2461,0 & 1186,0 & 0,438 & 0,662 & 0,462 & 0,644 & 50 & 50 & 0,663 \\
\hline $\begin{array}{l}\text { podjadanie } \\
\text { między posił- } \\
\text { kami }\end{array}$ & 2446,0 & 2604,0 & 1171,0 & $\begin{array}{c}- \\
0,541\end{array}$ & 0,588 & $\begin{array}{c}- \\
0,619\end{array}$ & 0,536 & 50 & 50 & 0,590 \\
\hline $\begin{array}{l}\text { ilość wypija- } \\
\text { nych płynów } \\
\text { w ciągu dnia }\end{array}$ & 2608,0 & 2442,0 & 1167,0 & 0,569 & 0,570 & 0,607 & 0,544 & 50 & 50 & 0,571 \\
\hline $\begin{array}{l}\text { znajomość } \\
\text { wartości od- } \\
\text { żywczych spo- } \\
\text { żywanych po- } \\
\text { siłków }\end{array}$ & 2500,5 & 2549,5 & 1225,5 & $\begin{array}{c}- \\
0,165\end{array}$ & 0,869 & $\begin{array}{c}- \\
0,178\end{array}$ & 0,859 & 50 & 50 & 0,866 \\
\hline $\begin{array}{l}\text { ile razy spo- } \\
\text { żywa mleko } \\
\text { i produkty } \\
\text { mleczne w } \\
\text { ciągu dnia }\end{array}$ & 2552,0 & 2498,0 & 1223,0 & 0,183 & 0,855 & 0,203 & 0,839 & 50 & 50 & 0,856 \\
\hline $\begin{array}{l}\text { częstość spo- } \\
\text { żywania sło- } \\
\text { dyczy }\end{array}$ & 2059,5 & 2990,5 & 784,5 & $\begin{array}{c}- \\
3,206\end{array}$ & 0,001 & $\begin{array}{c}- \\
3,278\end{array}$ & 0,001 & 50 & 50 & 0,001 \\
\hline $\begin{array}{l}\text { rozumienie } \\
\text { pojęcia BMI }\end{array}$ & 2350,0 & 2700,0 & 1075,0 & $\begin{array}{c}- \\
1,203\end{array}$ & 0,229 & $\begin{array}{c}- \\
1,456\end{array}$ & 0,145 & 50 & 50 & 0,230 \\
\hline
\end{tabular}


Jak wynika z tabeli 12 ze względu na poziom istotności $(\mathrm{p}<0,05)$, odnotowano statystycznie istotne różnice pomiędzy badanymi grupami, dotyczące wyników zagadnień: ile posiłków spożywa w ciągu dnia oraz częstość spożywania słodyczy.

\section{Dyskusja}

Cukrzyca typu 2 stanowi zarówno główny problem współczesnej medycyny, jak i problem społeczny i ekonomiczny. Sposób żywienia pełni zasadniczą rolę spośród wielu czynników przyczyniających się do rozwoju tej choroby [8].

Odpowiednio dobrana dieta, zawierająca prawidłową ilość owoców i warzyw, produktów zbożowych pełnoziarnistych, wyrobów mlecznych, jaj, ryb i chudego mięsa oraz odpowiednia jakość tłuszczy, odgrywa istotną rolę na stan odżywiania organizmu. Źle zbilansowana dieta przyczynia się między innymi do rozwoju nadwagi bądź otyłości, nadciśnienia tętniczego, zaburzenia gospodarki węglowodanowej co w efekcie odbija się na stan zdrowia i zapadłości na choroby przewlekłe [9].

W niniejszej pracy przeprowadzono badania zarówno kobiet chorujących na cukrzycę typu 2 jak i kobiety, u których nie zdiagnozowano cukrzycy typu $2 \mathrm{w}$ tej samej grupie wiekowej. Wykorzystano ankiety własnego autorstwa, które dotyczyły podstawowych zagadnień odnośnie zwyczajów żywieniowych. Kobiety udzielały odpowiedzi na pytania, dzięki którym można ocenić wpływ cukrzycy typy 2 na zwyczaje żywieniowe w życiu osób badanych.

W grupie badanej 48\% kobiet spożywa 4-5 posiłków dziennie, natomiast w grupie kontrolnej tylko $30 \%$ kobiet. Na pytanie czy dojada Pani między posiłkami 56\% respondentek z grupy badanej odpowiedziało tak, tak tylko czasami. Natomiast w grupie kontrolnej na to samo pytanie 58\% kobiet odpowiedziało, że tak tylko czasami. Słodycze to najczęściej wybierana przekąska miedzy posiłkami według Pań w obu grupach 31,5\% w grupie badanej i 30,4\% w grupie kontrolnej. 
Według Śmidowicz i Reguły $47 \%$ badanych spożywa 5 posiłków dziennie, jednocześnie 83\% badanych dojada między posiłkami. Najczęściej wybieraną przekąską okazały się owoce $22 \%$, spożywanie słodyczy jako przekąskę deklarowało 7\% [10].

Gacek w swoich badaniach pokazuje, że 78,3\% kobiet spożywa 4-5 posiłki dziennie, natomiast $30,5 \%$ respondentek ogranicza spożywanie słodyczy. $26,1 \%$ kobiet spożywa ryby przynajmniej raz w tygodniu. W badaniach własnych w grupie badanej $36 \%$ kobiet i $42 \%$ w grupie kontrolnej spożywa ryby raz w tygodniu. Według Piejko i współautorów 53,8\% ankietowanych spożywa ryby raz w tygodniu [11].

W diecie cukrzycowej zwraca się uwagę na sposób przygotowywania posiłków. Rekomendowane jest gotowanie lub gotowanie na parze [12]. W badaniach własnych za najczęściej stosowaną obróbką kulinarną Panie w grupie badanej deklarowały $43,9 \%$ gotowanie, gotowanie na parze, następnie $25,6 \%$ wybrało smażenie. W grupie kontrolnej odpowiednio gotowanie, gotowanie na parze $37,2 \%$ i smażenie $25,6 \%$.

Według Bulzackiej stosowaną techniką przyrządzania potraw 86\% ankietowanych odpowiedzieli smażenie, na drugim miejscu znajdywało się gotowanie 73,9\% [13]. Według Mędrela-Kuder 40\% ankietowanych deklarowało smażenie, natomiast pieczenie $19 \%$ i gotowanie $17 \%[14]$.

Ilość spożywanie posiłków w ciągu dnia, podjadanie miedzy posiłkami i dobór odpowiednich produktów spożywczych oraz ich odpowiednia obróbka kulinarna to najważniejsze elementy sposobu żywienia, które w ogromnym stopniu wpływają na prawidłową masę ciała i stan zdrowia. W badanej populacji zaobserwowano, że kobiety zmagające się z cukrzycą mają lepsze zwyczaje żywieniowe, niż kobiety zdrowe. Przy czym kobiety chorujące na cukrzycę typu 2 nie mają prawidłowych zwyczajów żywieniowych.

W grupie badanej zadano dodatkowe pytania związane z cukrzycą. Odpowiedzi były następujące: na pytanie czy zna Pani zasady diety 
w cukrzycy $80 \%$ ankietowanych odpowiedziało, że zna. Przy czym $82 \%$ kobiet uznała, że stosowanie diety jest utrudnieniem w życiu codziennym. Natomiast tylko 38\% respondentek wskazało, że raczej przestrzega zaleceń żywieniowych w codziennym życiu. 52\% Pań posiada umiejętność samodzielnej modyfikacji diety.

Według Kuryłek badane osoby uznały przestrzeganie diety jako kłopotliwy element terapii, większość badanych deklarowała znajomość zasad zdrowego odżywiania [15].

\section{Wnioski}

Na podstawie uzyskanych wyników można wyodrębnić następujące wnioski:

1. Pozytywne zachowania żywieniowe $\mathrm{w}$ grupie kobiet zmagających się z cukrzyca typu 2 dotyczą liczby posiłków i sposobu przyrządzania potraw. Negatywne zaś to podjadanie między posiłkami, wysokiej konsumpcji słodyczy oraz mniejsza częstotliwość wybierania ryb w porównaniu z kobietami zdrowymi.

2. Badane kobiety popełniły błędy dietetyczne, które mogą doprowadzać do rozwoju nadwagi i otyłości.

3. Takie zwyczaje żywieniowe pacjentów z cukrzycą typu 2 wskazują na konieczność prowadzenia rozmów wśród chorych na temat prawidłowego odżywiania w cukrzycy. Edukacja wpłynie na poprawę skuteczności leczenia choroby.

\section{Zalecenia dla praktyki pielęgniarskiej}

Podsumowując niniejszą pracę, dieta jest bardzo ważnym elementem w leczeniu cukrzycy. Odpowiednio zbilansowana może uchronić przed zapadalnością na choroby przewlekłe. Edukacja pacjentów chorych na cukrzycę wpłynęłaby pozytywnie na skuteczność leczenia choroby. 


\section{Bibliografia/Bibliography:}

1. Tokarski Z., Denys A. Zagrożenia zdrowia Publicznego. Wydawnictwo: Wolters Kluwer. Warszawa 2018:42-54.

2. Hołyńska A., Kucharska A., Sińska B., Panczyk M. Poziom wiedzy żywieniowej a sposób żywienia chorych na cukrzycę leczonych insuliną. XXXIX 2015:292.

3. Juzwiszyn J., Szmit A., Golemo K., Chabowski M., Milan M., Janczak D. Zachowania zdrowotne chorych na cukrzycę typu 2. 2016:233-239.

4. Pączek L., Mucha K. Choroby wewnętrzne. Podręcznik dla studentów pielęgniarstwa i położnictwa. Wydawnictwo Lekarskie PZWL. Warszawa: 2006.

5. Delamater A. Zwiększenie świadomości udziału pacjenta w procesie leczenia. Diabetologia po dyplomie 2006;3:35-40.

6. Kokoszka A. Krótka metoda oceny radzenia sobie $\mathrm{z}$ chorobą: wersja dla mężczyzn i kobiet. Diabetologia Praktyczna 2008;9:1-11.

7. Czech A. Dążenie do opartej na dowodach personalizacji leczenia cukrzycy- konieczność nowego ujęcia roli standardów i algorytmów terapeutycznych. Medycyna metaboliczna 2010;14:9-12.

8. Jarosz M. Normy żywienia dla populacji polskiej - nowelizacja. IŻŻ. Warszawa 2012.

9. Suliga E. Zachowania zdrowotne związane z żywieniem osób dorosłych i starszych. Hygeia Public Health 2010:296-300.

10. Śmidowicz A., Reguła J. Analiza zachowań żywieniowych predysponujących do rozwoju chorób żywieniowozależnych u osób po 40. roku życia. Forum zaburzeń metabolicznych 2016;7,1:44-50. 
11. Piejko L., Nawrat-Szołtysik A., Kopeć D., Broncel-Czekaj D., Nowak Z. Jakość diety i wybrane zachowania zdrowotne dorosłych chorych na cukrzyce typu 2. Forum Zaburzeń Metabolicznych 2018;9,1:36-44.

12. Biernat J. Żywność, żywienie, zdrowie. Wyd. ASTRUM. Wrocław 2001.

13. Bulzacka M., Mikulska A. Styl życia chorych na cukrzyce typu 2 w wieku 50-55 lat a zapotrzebowanie na edukacje zdrowotną. Ann. Univ. Mariae Curie-Skłodowska 2007;306-316.

14. Mędrela-Kuder E. Prawidłowa dieta w cukrzycy typu II jako forma rehabilitacji chorych. 2011;62,2:219-223.

15. Kuryłek B., Jakubowska I., Górska M. Wpływ sposobu leczenia na jakość życia chorych z cukrzycą typu 2. Medycyna Metaboliczna 2012;16:25-27 